\title{
Effects of Plant Leaf Extracts on Egg-Masses Hatching and Juveniles Mortality of the Root-Knot Nematode, Meloidogyne Javanica
}

\author{
Aanany, A.M.*; Mahmoud, N.A.**; El-Mesalamy, A.F.** and Abdel-Hafeez, A.R. ${ }^{* *}$ \\ * Agric. Zool. and Nematol. Dept., Fac. of Agric. Al-Azhar University. Cairo. \\ ${ }^{* *}$ Agric. Zool. and Nematol. Dept., Fac. of Agric. Al-Azhar University. Assiut Branch.
}

\section{Abstract}

The effects of plant extracts from fresh leaves of five different plants; Acasia arabica, Ziziphusspina christi, Eucalyptus camaldulensis, Lawsonia inermis and Dalbergia sissoo were evaluated against egg-masses hatching and juvenile mortality of root-knot nematode, Meloidogyne javanica under laboratory conditions. Results revealed that, all treatments extracts had significantly $(P<0.05)$ reduced in the hatching of egg-masses. The maximum reduction occurred in Acasia arabica with the concentration (S) was (97.13\%) and the concentration (S/2) was (89.99\%), whereas the minimum reduction caused by Ziziphusspina christi with the concentration (S) was $(45.49 \%)$ and the concentration (S/2) was $(24.63 \%)$. The same effects of plant extracts against $M$. javanica juveniles, the most mortality of second stage juveniles was observed in leaf extracts of Acasia arabica, and Dalbergiasissoo with the concentration (S) was (100\%) as regarding to and the concentration (S/2) was (100\%) in Dalbergia sissoo, while the least in Ziziphusspina christi with the both concentrations $S$ and $S / 2$ (17.0 and 5.33\%), respectively.

Keywords: Root-knot nematode, Meloidogyne javanica, plant leaf extracts.

\section{Introduction}

Plant-parasitic nematodes are major pests in many countries, particularly in the tropics and subtropics, where they are recognized as the cause of serious yield losses on a wide range of crops (Luc et al., 2005; Sasser\&Freckman, 1987). Among all plant-parasitic nematodes, root-knot nematodes (Meloidogyne spp.) are economically the most important and agriculture productivity and quality limiting pathogens (Javed et al., 2006). Nematode control is largely based on synthetic nematicides, which is expensive and potential risk to environment, consequently non-target organisms. For more acceptable alternatives to chemicals, the possibilities are being investigated of exploiting nematode-antagonistic plants for the management of plant parasitic nematodes (Chitwood, 2002 and Akhtar, 2004). Current management of nematodes is focused on plant resistance, crop rotation, cultural practices or chemical nematicides (Chitwood, 2002). Because of these inconveniences, scientists found natural product with nematicidal activity such as 
plant extract, root exudates, plant volatiles etc. The use of plant extracts as an alternative to synthetic pesticides for control of root-knot nematodes is becoming important. In recent years, research on this topic has increased rapidly in the Mediterranean coast (Ntallie et al., 2011; Andres et al., 2012). Narpinderjeet et al., (2002) found that neem cake and Rakshak gold (neem-based product) were effective against eggs of Meloidogyne incognita.Yasmin et al., (2003) found that extract of neem seed was more effective against juvenile of $M$. javanica than bark and leaf. Pot experiment with all the extracts gave significant suppression in root galling and population of the nematode. Hadian et al., (2011) reported that neem seed powder $50 \mathrm{~g} / \mathrm{kg}$ soil decreased root knot index from 4.7 (control) to 0.25 and disease severity from $85 \%$ (control) to $12 \%$ on tomato inside the glass house. Therefore, the aim of this research paper was study to the nematicidal activity of plant extracts from fresh leaves of five different plants on Meloidogyne javanica juveniles in-vitro.

\section{Materials and Methods}

Root knot nematode Meloidogyne javanica was selected as test organism. The culture of root knot nematode, Meloidogyne javanica, is maintained in pot eggplant root inside the glasshouse. The infected plants will be uprooted, carefully washed in running tap water and egg-masses will be collected in to Petri dishes containing distilled water. 10 gram of fresh leaves from Acasia arabica, Ziziphusspina christi, Eucalyptus camaldulensis, Lawsoniai nermis and Dalbergias issoo were separately mixed with $50 \mathrm{ml}$ distilled water in an electric blender for 3 minutes. The mixture was allowed to stand 72 hours and filtered through filter papers. The filtrate was considered as standard and assayed against juveniles and egg-masses. The evaluation was carried out in clean Petri dishes. There were 5 Petri dishes in 3 replications for each treatment. The Petri dishes with distilled water was taken as control. For studying the juveniles' mortality, 100 second stage juveniles of $M$. javanica in $1 \mathrm{ml}$ distilled water were suspended in $10 \mathrm{ml}$ of different leaf extracts. All the Petri dishes were kept at ambient temperature laboratory. After $12,24,48,72$ and 96 hour's incubation, all dead and alive juveniles were counted with the aid of inverted microscope at magnification $100 \mathrm{X}$. The dead juveniles attained the shape of straight line and the mortality was ensured by touching the juvenile with a fine needle. The ratio of dead nematodes/number of total nematodes expressed the percentage mortality. To determine the effect on five egg-masses hatching medium size egg masses hand-picked from the galls of eggplant root were placed in each of Petri dishes containing $10 \mathrm{ml}$ of leaf extracts. Egg-masses kept in distilled water served as control. Each treatment was replicated 3 times. After 10 days exposure, the number of juveniles hatched was counted. Data were thenanalyzed according to Duncan's multiple range tests (1955). 


\section{Results and Discussion}

The aqueous plant leaf extracts of Acacia, Buckthorn, Red gum, Henna and Asersus were highly nematicidal effect to second stage juveniles of $M$. javanica in vitro (Table $1 \&$ Fig. 1). The nematode mortality was in the range of $(0.0$ to $100.0 \%)$ compared to $\mathrm{S} / 2$ and $\mathrm{S} \%$. Results revealed that the nematode mortality with plant leaf extracts were increased with the increase of the exposure time from 12 to $96 \mathrm{~h}$. Asersus extract was more effective against second stage juveniles of nematode at standard concentration of $\mathrm{S}$, followed by aqueous extracts of Acacia, Red gum, Henna, and Buckthorn were $(100,100,34,20.33 \& 17 \%)$, respectively after $96 \mathrm{~h}$ of exposure time. At the concentration of $\mathrm{S} / 2$, the aqueous plant leaf extracts caused nematode mortalities of $(100,92,17.67,7.66 \& 5.33 \%)$ respectively with Asersus, Acacia, Red gum, Henna, and Buckthorn after $96 \mathrm{~h}$ of exposure time.

Table (1): Effect of Five different leaf extracts on mortality percentage of second stage juveniles of the root-knot nematode, Meloidogyne javanica.

\begin{tabular}{|c|c|c|c|c|c|c|c|}
\hline \multirow{2}{*}{ Plant extracts } & \multirow{2}{*}{$\begin{array}{c}\mathrm{PH} \\
\text { value }\end{array}$} & \multirow{2}{*}{ Conc. } & \multicolumn{5}{|c|}{ Nematode mortality (\%) after hours } \\
\hline & & & 12 hrs. & 24 hrs. & 48 hrs. & 72 hrs. & 96 hrs. \\
\hline Acacia & 7.00 & $\mathrm{~S} / 2$ & $2.33 \mathrm{de}$ & 4.00 ef & $63.33 c$ & $79.33 \mathrm{~b}$ & $92.00 \mathrm{~b}$ \\
\hline (Acasia arabica) & 7.00 & S & $7.66 \mathrm{c}$ & $14.33 \mathrm{c}$ & $94.00 \mathrm{~b}$ & $100.00 \mathrm{a}$ & $100.00 \mathrm{a}$ \\
\hline Buckthorn & 7.00 & $\mathrm{~S} / 2$ & $0.00 \mathrm{e}$ & $0.00 \mathrm{~g}$ & $0.00 \mathrm{f}$ & $0.00 \mathrm{f}$ & 5.33 e \\
\hline (Ziziphusspina christi) & 7.00 & S & $0.00 \mathrm{e}$ & $0.00 \mathrm{~g}$ & $0.66 \mathrm{f}$ & 2.33 ef & $17.00 \mathrm{~d}$ \\
\hline Red gum & 7.00 & $\mathrm{~S} / 2$ & $1.66 \mathrm{de}$ & $2.00 \mathrm{fg}$ & $3.33 \mathrm{f}$ & $5.33 \mathrm{def}$ & $17.67 \mathrm{~d}$ \\
\hline (Eucalyptus camaldulensis) & 7.00 & $\mathrm{~S}$ & $6.33 \mathrm{~cd}$ & $7.00 \mathrm{~d}$ & $8.66 \mathrm{e}$ & $9.00 \mathrm{~d}$ & $34.00 \mathrm{c}$ \\
\hline Henna & 7.00 & $\mathrm{~S} / 2$ & $3.00 \mathrm{de}$ & 4.00 ef & 5.00 ef & $6.33 \mathrm{de}$ & $7.66 \mathrm{e}$ \\
\hline (Lawsonia inermis) & 7.00 & S & 4.33 cde & $5.66 \mathrm{de}$ & $14.00 \mathrm{~d}$ & $19.33 \mathrm{c}$ & $20.33 d$ \\
\hline Asersus & 7.00 & $\mathrm{~S} / 2$ & $69.00 \mathrm{~b}$ & $97.00 \mathrm{~b}$ & $99.67 \mathrm{a}$ & $100.00 \mathrm{a}$ & $100.00 \mathrm{a}$ \\
\hline (Dalbergia sissoo) & 7.00 & S & $100.00 \mathrm{a}$ & $100.00 \mathrm{a}$ & $100.00 \mathrm{a}$ & $100.00 \mathrm{a}$ & $100.00 \mathrm{a}$ \\
\hline $\begin{array}{l}\text { Distilled Water } \\
\quad \text { (Control) }\end{array}$ & 7.00 & 0 & $0.00 \mathrm{e}$ & $0.00 \mathrm{~g}$ & $0.00 \mathrm{f}$ & $0.00 \mathrm{f}$ & $0.00 \mathrm{f}$ \\
\hline
\end{tabular}

Values in each column followed by the same letters are no significant at $\mathrm{P}<0.05$ according to Duncan's multiple-range test. 

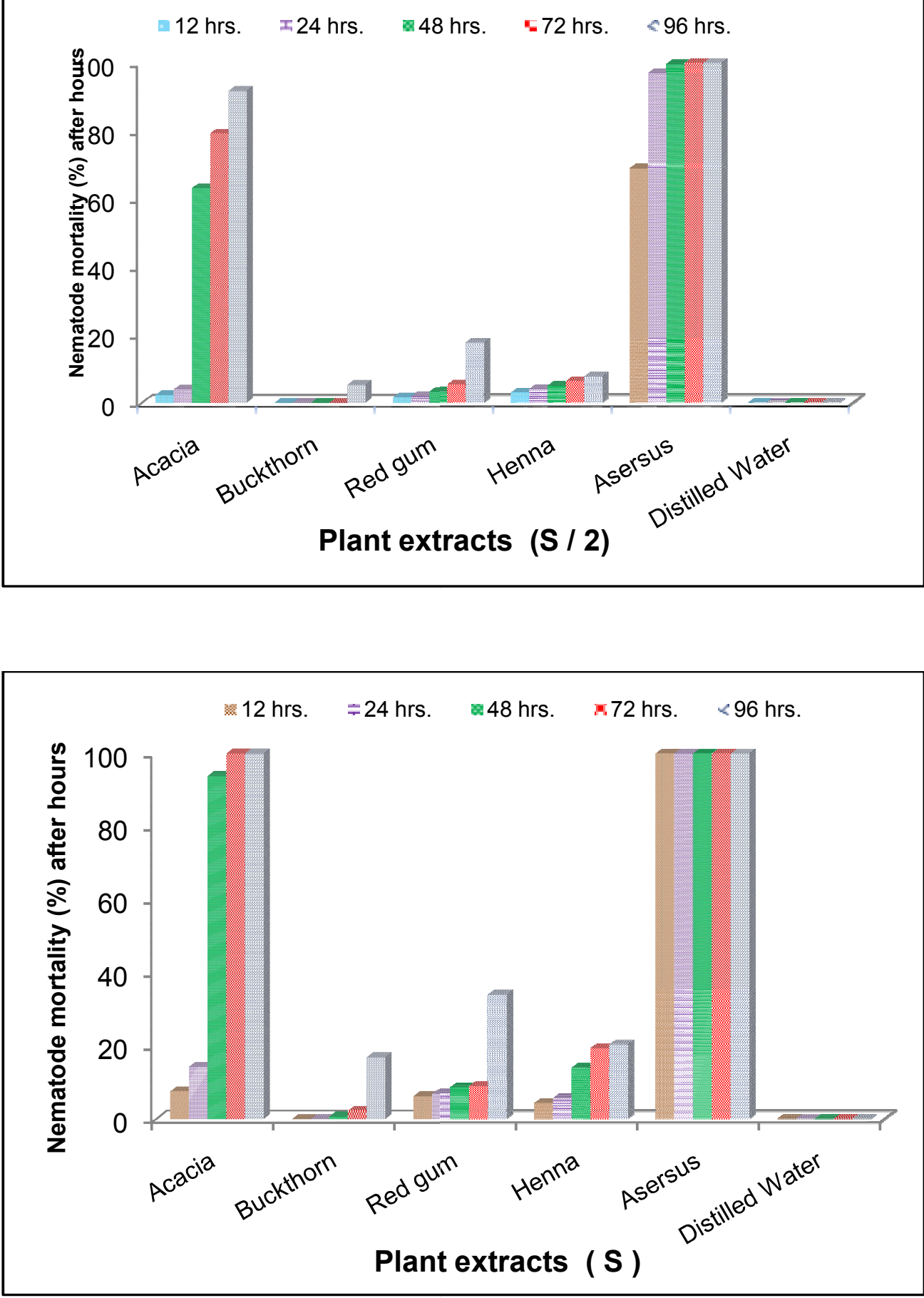

Fig. (1): Effect of Five different leaf extracts on mortality percentage of second stage juveniles of the root-knot nematode, Meloidogyne javanica. 
As regarding to egg-masses hatchability, data in (Table 2 \& Fig. 2) indicate the effect of different concentration of aqueous leaf extracts on the number of eggs, The percentage hatch inhibition indicated that $(\mathrm{S})$ concentration of aqueous extracts of Acasia gave the highest inhibition of egg-masses hatching (97.13\%). this was followed by Henna, Asersus, Red gum, and Buckthorn with (93.91, 92.80, 89.30 \& $45.49 \%$ ) inhibition, respectively. At the concentration (S/2) of aqueous leaf extracts of Acasia gave the highest inhibition of egg-masses hatching (89.99\%) followed by Asersus, Henna, Red gum, and Buckthorn with (87.97, 86.08, 70.82 \& 24.63\%) inhibition, respectively.

Table (2): Effect of Five different leaf extracts on egg-masses hatching of the rootknot nematode, Meloidogynejavanica.

\begin{tabular}{|c|c|c|c|c|}
\hline $\begin{array}{c}\text { Plant } \\
\text { extracts }\end{array}$ & Conc. & $\begin{array}{l}\text { No. of eggs } \\
\text { hatched } 10 \text { days } \\
\text { after exposure }\end{array}$ & $\begin{array}{l}\% \text { of eggs } \\
\text { hatched } 10 \text { days } \\
\text { after exposure }\end{array}$ & $\begin{array}{c}\% \text { inhibition of } \\
\text { egg hatching in } \\
10 \text { days }\end{array}$ \\
\hline Acacia & $S / 2$ & 143 ef & 10.01 & 89.99 \\
\hline (Acasia Arabica) & s & $41 \mathrm{f}$ & 2.87 & 97.13 \\
\hline Buckthorn & $\mathrm{S} / 2$ & $1077 \mathrm{~b}$ & 75.37 & 24.63 \\
\hline (Ziziphusspina Christi ) & S & $779 c$ & 54.51 & 45.49 \\
\hline Red gum & $\mathrm{S} / 2$ & $417 d$ & 29.18 & 70.82 \\
\hline (Eucalyptus camaldulensis ) & $S$ & 153 ef & 10.70 & 89.30 \\
\hline Henna & $\mathrm{S} / 2$ & $199 \mathrm{e}$ & 13.92 & 86.08 \\
\hline (Lawsonia inermis ) & $S$ & 87 ef & 6.09 & 93.91 \\
\hline Asersus & $\mathrm{S} / 2$ & $172 \mathrm{e}$ & 12.03 & 87.97 \\
\hline (Dalbergia sissoo ) & $s$ & 103 ef & 7.20 & 92.80 \\
\hline $\begin{array}{l}\text { Distilled Water } \\
\text { (Control) }\end{array}$ & & $1429 a$ & 100.00 & 0.00 \\
\hline
\end{tabular}

Values in each column followed by the same letters are no significant at $\mathrm{P}<0.05$ according to Duncan's multiple-range test. 

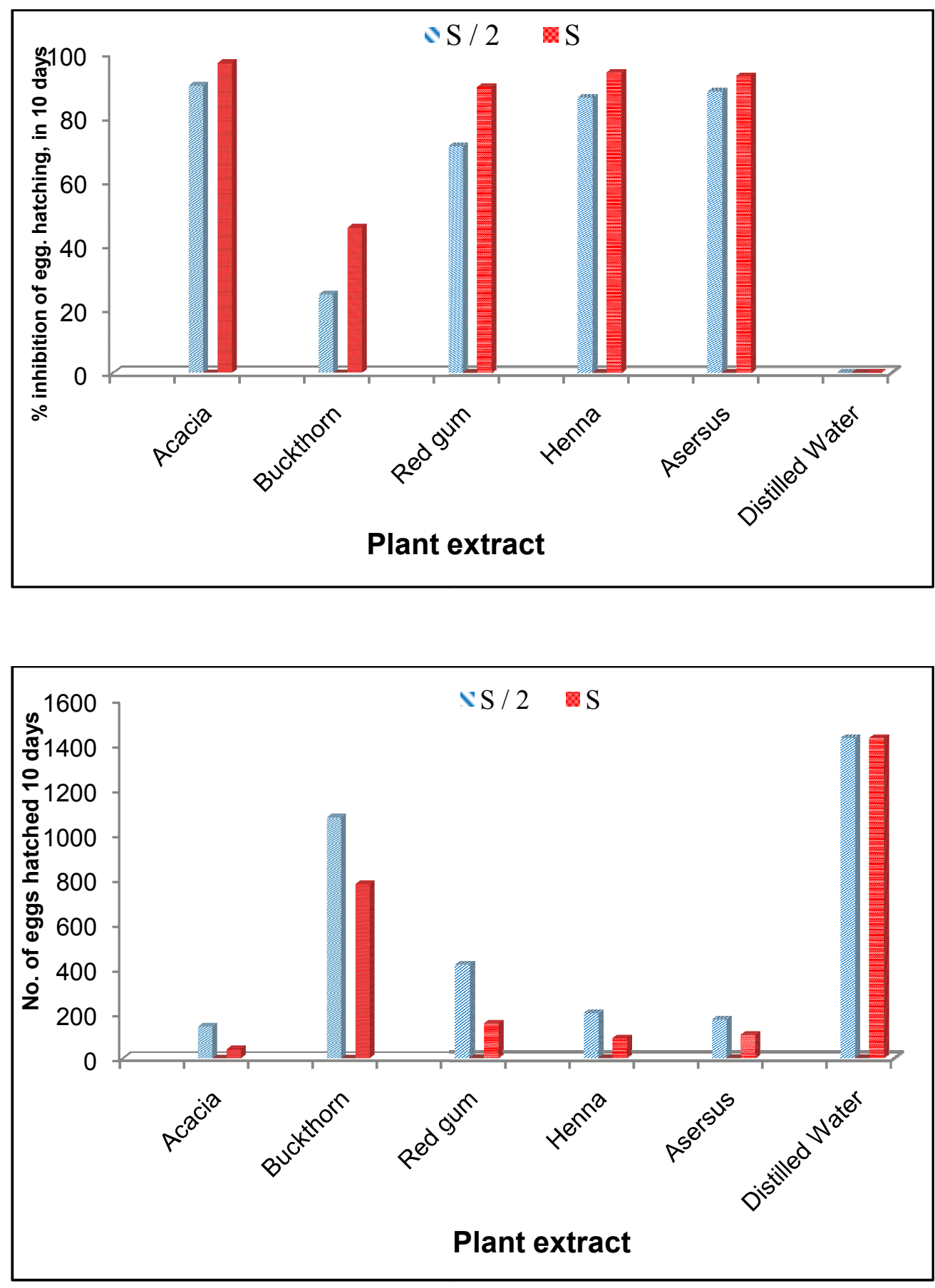

Fig (2): Effect of Five different leaf extracts on egg-masses hatching of root-knot nematode, Meloidogynejavanica. 
Our results are in keeping of those of (Pandey et al., 2000, Inouye et al., 2001, Ibrahim et al., 2006, Dawar et al., 2007, Batish et al., 2008, Sultana, 2011, Latif et al., 2014 and El-Baha, 2017) who reported that aqueous extracts of tested plant leaves showed nematicidal effect against Meloidogyne ssp. Root-knot nematode reduced hatching of egg-masses, increased mortality of juveniles with an increase in exposure of time and showed efficiency in the control of root-knot nematode,Meloidogyne ssp.

\section{References}

Akhtar, M. (2004). Current options in integrated management of plant-parasitic nematodes. Integrated Pest Management Review, 2: 187-197.

Andres, M.F.; Coloma, A.G.; Sanz, J.; Burillo, J. and Sainz, P. (2012).Nematicidal activity of essential oils: a review. Phytochemistry Reviews, 11: 371-390.

Batish, D.R.; Singh, H.P.; Kohli, R.K. and Kaur, S. (2008). Eucalyptus essential oil as a natural pesticide. Forest Ecology and Management, 256, 21662174 .

Chitwood, D. J. (2002). Phytochemical based strategies for nematode control. Annual Review of Phytopathol., 40: 221-249.

Duncan, D.B. (1955). Multiple range and multiple F tests.Biometrics, 11: 1- 4.

Dawar, S.; Younus, S.M. and Zaki, M.J. (2007). Use of Eucalyptus sp. in the control of Meloidogynejavanica root-knot nematode. Pak. J. Bot., 39: 22092214.

El-Baha, A.M.; El-Sherbiny, A. A.; Salem, M. Z. M.; Sharrawy, N. M. M.; and Mohamed, N. H. (2017). Toxicity of essential oils extracted from Corymbiacitriodora and Eucalyptus camaldulensis leaves against Meloidogyne incognita under laboratory conditions.Pakistan Journal of Nematology 35 (1): 93-104.

Hadian, S., Rahnama, K ., Jamali, S., Eskandari, A., (2011). Comparing Neem extract with chemical control on Fusariumoxysporum and Meloidogyne incognita complex of tomato. Advances in Environmental Biology, 5(8): 2052- 2057.

Ibrahim, S. K.; Traboulsi, A. F. and El-Haj, S.(2006).Effect of essential oils and plant extracts on hatching, migration and mortality of Meloidogyne incognitaPhytopathol. Medit. 45: 238-246.

Inouye, S.; Takizawa, T. and Yamaguchi. (2001). Antibacterial activity of essential oil and their major constituents against respiratory tract pathogens by gaseous contact. J. Antimicrobial chemotherapy, 47: 565-573. 
Javed, N.; Anwar, S. A.; Inam-ul-haq, M.; Ahmad, R. \& Khan, H. U. (2006). Effect of neem formulations applied as soil drenching on invasion and development of root-knot nematode, Meloidogynejavanica, 244-247. Proceeding of International Symposium on Sustainable Crop Improvement and Integrated Management. University of Agriculture, Faisalabad, Pakistan, Pakistan on September 14-16,

Latif, R.; Abbasi, M.W.; Zaki, M.J. and Khan, D. (2014). Nematicidal activity of bark of some tree species against root knot nematode Meloidogynejavanica. Fuuast. J. biol., 4: 247-251.

Luc, M.; Sikora, R. A. and Bridge, J. (2005). Plant parasitic nematodes in subtropical and tropical agriculture. Wallingford, UK, CABI Publishing, 871 pp.

Narpinderjeet, R.; Sakhuja, P.K. and Singh Inderjit.( 2002). Management of rootknot nematode Meloidogyne incognita in Abelmoschusesculentus through botanical extracts and organic amendments. Indian Journal of Nematology., $32(2)$.

Ntallie, N. G.; Ferrari, F.; Giannakouc, I. and Menkissoglu-Spiroudia, U. (2011). Synergistic and antagonistic interactions of terpenes against Meloidogyne incognita and the nematicidal activity of essential oils from seven plants indigenous to Greece. Pest Management Science,

Pandey, R.; Kalra, A.; Tandon, S.; Mehrotra, N.; Singh, H. N. and Kumar, S. (2000). Essential oils as potent sources of nematicidal compounds. J. Phytopathol., 148: 501-502.

Sasser, J. N. and Freckman, D. W. (1987). A World Perspective on Nematology. Pp. 7-14. The role of society. In: Vistas in Nematology. (Eds: J. A. Veech\& D. W. Dickerson). A commemoration of the Twenty-fifth Anniversary of the Society of Nematologists. Hyattsville, MD: Society of Nematologists, Inc., 509 pp.67: 341-351.

Sultana, N.; Akhter, M.; Saleem, M. and Ali, Y. (2011). Nematicidal effect of Acacia niloticaand Gymnemasylvestris against second stage juveniles of Meloidogyne incognita. J. Entomol. and Nematol.,3: 25-29.

Yasmin, L.; Rashid, M.H.; Uddinm, N. M.; Hossain, M.S.; Hossain, M.E. and Ahmed, M.U. (2003). Use of Neem Extract in Controlling RootknotNematode (Meloidogynejavanica) of Sweet -gourd. Pak. J. Plant Pathol., 2 (3): 161-168. 


\section{تأثير مستخلص أوراق بعض النباتات علي معدل فقس البيض وموت يرقات}

\section{MeloidogyneJavanica نيماتودا تعقد الجذور}

$$
\begin{aligned}
& \text { عبدالمنعم السعيد عناني*، نشأت عبد العزيز محمود**، أنس فرج المسلمي**"، }
\end{aligned}
$$

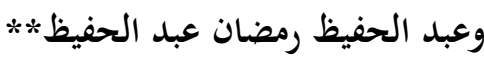

$$
\begin{aligned}
& \text { *قسم الحيوان الزراعي والنيماتودا - كلية الزراعة - جامعة الأزهر - القاهرة. }
\end{aligned}
$$

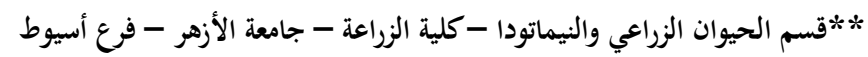

$$
\text { الملخص العربي }
$$

استهدفت الدراسة تقييم فاعلية خمسة أنواع من الأوراق الخضراء المفرومة على هيئة

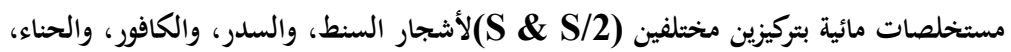

والسرسوع والمنزرعة بكثرة في محافظة أسوان واستخدامها كبدائل للمبيدات الكيميائية في

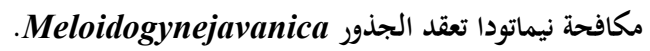

ولقد أوضحت النتائج أن جميع مستخلصات الأوراق المختبرة قد أدت إلي تقليل معدلات

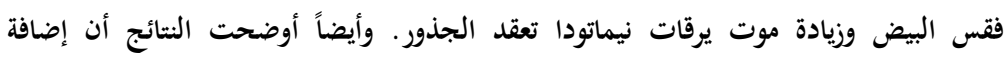

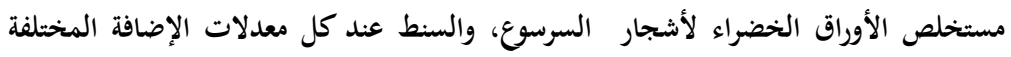

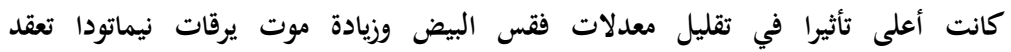
الجذور Meloidogynejavanica. 